\title{
A closer look at nitrification in pelagic sediments
}

\author{
E. Suess, ${ }^{1}$ P. J. Müller, ${ }^{2}$ H. S. Powell ${ }^{1}$ and C. E. Reimers ${ }^{1}$ \\ School of Oceanography, Oregon State University, Corvallis, Oregon $97331^{1}$ U.S.A. \\ and Geologisches Institut, Universität Kiel, Olshausenstrasse 40/60 2300 Kiel, Germany ${ }^{2}$
}

(Received May 23, 1980; Accepted July 2, 1980)

\begin{abstract}
Nutrient profiles in Southwest Pacific interstitial solutions suggest that in environments of oxic pelagic sedimentation microbially mediated nitrification is recognizable as a two-step process. During the first step partially oxidized nitrogenous intermediaries accumulate in distinctive ammonia and nitrite maxima along with nitrate. During the second step nitrification continues and all intermediate species are fully oxidized to nitrate. Both steps occur within a zone that corresponds in thickness to the biologically active surface layer. Similarly, experimental nitrogen regeneration from decomposition of plankton in seawater (VON BRAND and RAKESTRAW, 1941: VON BRAND et al., 1942) suggests that each step corresponds to a distinct reaction in the microbially mediated transformation of $\mathrm{N}$-org $\rightarrow \mathrm{NH}_{3} \rightarrow \mathrm{NO}_{2} \rightarrow$ $\mathrm{NO}_{3}$. The resolution of distinct reaction zones in pore water nutrient profiles possibly depends on the nature and mode of supply of the organic matter undergoing nitrification or reflects the spatial succession downcore of microbial populations capable of deamination, ammonium oxidation and nitrite oxidation, respectively. Finally, stoichiometric ratios of nutrients in the free water column - here demonstrated on published data from Saanich Inlet - reflect the same two steps of nitrification as delineated by the dissolved pore water species. Future pore water studies should include dissolved oxygen measurements as well as accurate $\Sigma \mathrm{CO}_{2}, \mathrm{PO}_{4}$ and nitrogenous species profiles, to verify and better quantify these separate steps in nitrification mechanism of oxic pelagic sediments.
\end{abstract}

\section{INTRODUCTION}

Ever since the ratios among dissolved nutrients and metabolites in pore solutions of marine sediments were discovered to reflect different mechanisms of organic matter decomposition, a great number of decomposition models have been proposed (Aller, 1977; BERNER, 1972; BALzER, 1978; HARTMANN et al., 1976; Murray and IrVIne, 1895; Murray et al.,1978; a.o.). This approach was further stimulated by the applicability of stoichiometric models developed by chemical and biological oceanographers for nutrient regeneration patterns in the free water column to those of interstitial solutions of marine sediments. Recently, it has been recognized that inorganic secondary reactions between metabolites and solid sediment phases greatly limit the nutrient regeneration models. It appears that only in environments of slow sedimentation, where secondary reactions are insignificant and metabolites simply accumulate, such models can be applied (BERNER, 1977; EMERSON, 1976; MARTENS et al., 1978; Froelich et al., 1979; and SuEss, 1979).

Oxic environments of slow pelagic sedimentation comprise the dominant areas of recent sediment accumulation in the oceans and hence the major sites of organic matter mineralization. BENDER et al. (1977) have first suggested that microbially mediated nitrification and denitrification are two prominent regeneration mechanisms at the sediment-water interface of pelagic sediments. We will extend those considerations with a closer look at nitrification in pelagic sediments and at selected water column data and experimental nitrification reactions.

Ideally, regeneration ratios in pore waters of oxygenated sediments should be:

(1) $-\Delta \mathrm{O}_{2}: \Delta \mathrm{NO}_{3}: \Delta \mathrm{PO}_{4}: \Delta \Sigma \mathrm{CO}_{2}=$ 


\section{$138: 16: 1: 106$}

based on an overall decomposition reaction:

(2) $\left(\mathrm{CH}_{2} \mathrm{O}\right)_{106}\left(\mathrm{NH}_{3}\right)_{16}\left(\mathrm{H}_{3} \mathrm{PO}_{4}\right)+138 \mathrm{O}_{2} \rightarrow$ $106 \mathrm{CO}_{2}+16 \mathrm{HNO}_{3}+\mathrm{H}_{3} \mathrm{PO}_{4}+122 \mathrm{H}_{2} \mathrm{O}$ and the assumption that all $\mathrm{NH}_{3}$ released by deamination is quickly oxidized to nitrate.

We present evidence here that this overall reaction may proceed in at least two resolvable steps with distinct steady state nutrient concentration patterns. During the first step partially oxidized nitrogenous intermediaries are formed and not immediately converted to nitrate as is generally assumed. Then during a second step they are fully oxidized.

This stepwise process in decomposition of organic matter by oxygen consumption is also evident in the primary ammonia and primary nitrite maxima of water column nutrients (COHEN, 1978) and in experimental nitrogen regeneration from decomposition of plankton in seawater (VON BRAND and RAKESTRAW, 1941; VON BRAND et al., 1942). We develop our view of a stepwise nitrification process partially from such available water column nutrient and experimental data where overall nitrification is resolved into deamination, ammonium and nitrate oxidation and partially from our own measurements of regeneration products in pore waters of oxygenated near-surface sediments from the southwest Pacific.

\section{RESULTS}

The area of sampling in the Southwest Pacific and the core locations are shown in Fig.

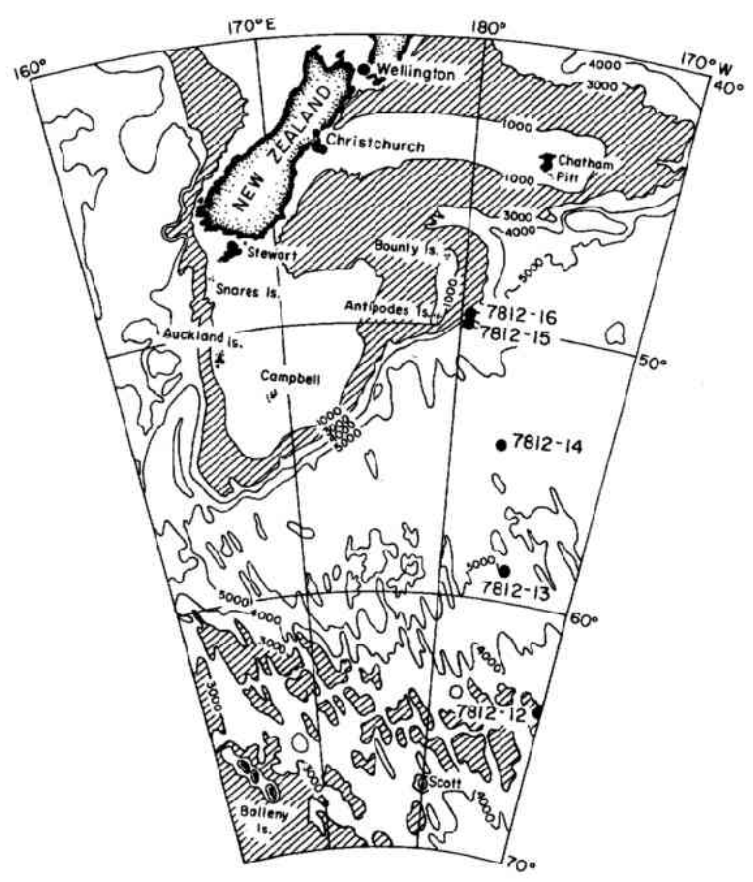

Fig. 1. SW Pacific station locations of three box cores (7812-12, 7812-14 and 7812-15) and two deep hydrocasts (7812-13 and 7812-16) for interstitial and bottom water chemical analyses.

1 and Table 1. The sediments there are oxygenated siliceous clays from the center of the SW Pacific Basin with manganese and iron oxides, carbonate silts from the Campbell Plateau and diatomaceous oozes from the north flank of the Pacific Antarctic Ridge. This ridge underlies the highly productive waters of the Circumpolar current.

The sediments were obtained with a Reinecktype box corer which ensures preservation of

Table 1. Station locations

\begin{tabular}{|c|c|c|c|}
\hline Station No. & $\begin{array}{c}\text { Latitude } \\
\text { longitude }\end{array}$ & $\begin{array}{l}\text { Water depth } \\
\text { (m) }\end{array}$ & Remarks \\
\hline $7812-12$ & $\begin{array}{l}63^{\circ} \\
169^{\circ} 43.3^{\prime} \mathrm{s} \cdot \mathrm{W}\end{array}$ & 2875 & Diatomaceous ooze \\
\hline $7812-13$ & $\begin{array}{l}58^{\circ} \\
174^{\circ} 33.0^{\circ} 30^{\prime} \mathrm{W}\end{array}$ & 4980 & Bottom water \\
\hline $7812-14$ & $\begin{array}{l}54^{\circ} 07.8^{\prime} \mathrm{S} \\
177^{\circ} 24.0^{\prime} \mathrm{W}\end{array}$ & 5446 & $\begin{array}{l}\text { Siliceous clay with } \\
\text { Mn-nodules }\end{array}$ \\
\hline $7812-15$ & $\begin{array}{l}49^{\circ} 38.1^{\prime} \mathrm{S} \\
179^{\circ} 33.3^{\prime} \mathrm{W}\end{array}$ & 3989 & $\begin{array}{l}\text { Calcareous silt with } \\
\text { Mn-nodules }\end{array}$ \\
\hline $7812-16$ & $\begin{array}{l}49^{\circ} 35.6^{\prime} \mathrm{S} \\
179^{\circ} 37.2^{\prime} \mathrm{W}\end{array}$ & 3560 & Bottom water \\
\hline
\end{tabular}


the surface layers, and pore waters were separated by pressure filtration at in situ temperatures immediately after core recovery. All analyses were performed on board ship in less than 6 hours after coring. Aliquots for shorebased total dissolved organic carbon and nitrogen determinations were also taken immediately and sealed in glass ampoules. Analytical methods were those described by HARTMANN et al. (1976); BALZER (1978); Gordon et al. (1975); and SuEss (1976).

Figures 2a-c illustrate depth-concentration profiles of all dissolved constituents from diatomaceous ooze, siliceous clay and carbonate silt facies (Core 7812-12, Core 7812-14, Core $7812-15$, respectively). Also included are con- centrations of the same constituents in free bottom water samples; Stations 7812-13 and 7812-16.

All three sediment pore water profiles show increasing nitrification with increasing depth and well developed primary nitrite and ammonia maxima associated with the steepest gradient of nitrate increase. The profile from Core 7812-14 shows further nitrite and ammonia maxima between 22 and $30 \mathrm{~cm}$ of depth. All maxima are accompanied by high concentrations of other labile constituents; i.e. dissolved organic carbon (DOC), carbohydrates, organic nitrogen (DON) and urea (as $\mu \mathrm{M}-\mathrm{N}$ ), attesting to their transient and partially oxidized nature. The depths below the interface in which these
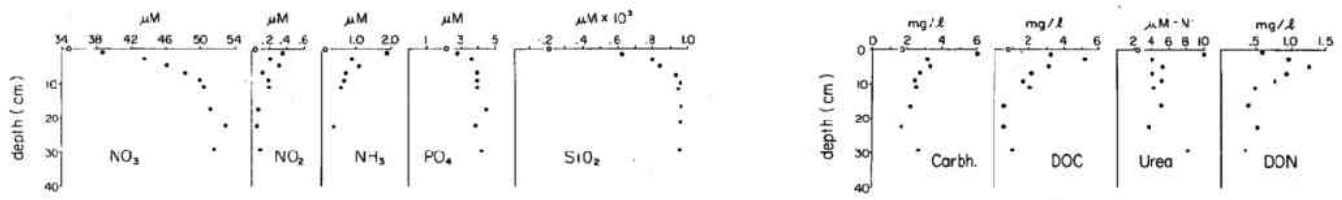

Fig. 2A
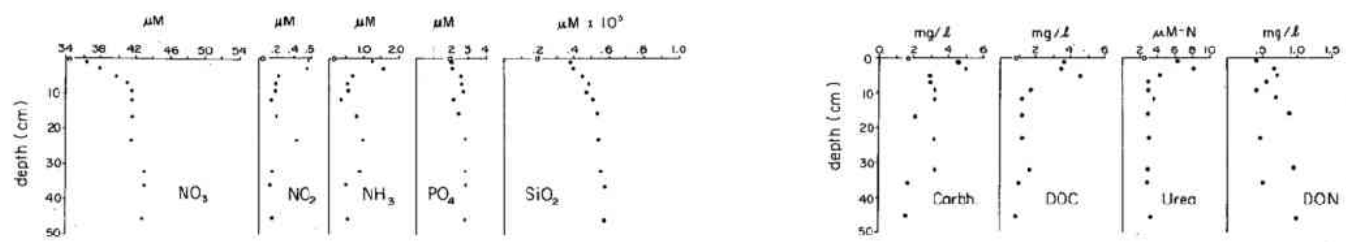

Fig. 2B
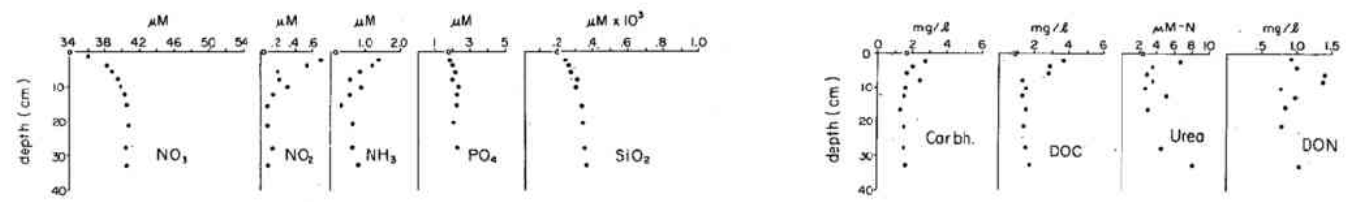

Fig. 2C

Fig. 2. Dissolved interstitial nutrients $\left(\mathrm{SiO}_{2}, \mathrm{NO}_{3}, \mathrm{PO}_{4}, \mathrm{NO}_{2}, \mathrm{NH}_{3}\right)$ and organic constituents (carbohydrates, dissolved organic carbon, urea and total dissolved organic nitrogen) in pore waters of SW Pacific oxic pelagic sediments and overlying bottom waters. Fig. $2 A=$ diatomaceous ooze facies, Fig. $2 B=$ siliceous clay facies, Fig. $2 C=$ calcareous silt facies. 
intermediary constituents are present in high concentrations is $5 \mathrm{~cm}$ for the diatomaceous ooze, $4 \mathrm{~cm}$ for the pelagic clay, and $10 \mathrm{~cm}$ for the carbonate silt and probably reflect the thickness of the biologically active surface layer or sediment permeability to oxygen. Dissolved $\mathrm{SiO}_{2}$ and $\mathrm{PO}_{4}$ gradually increase with depth, most likely reflecting simple accumulation. Dissolved $\mathrm{SiO}_{2}$ appears to be controlled by the amount of opaline silica of the sediment or by a combination of silica input and rates of dissolution, diffusion and sedimentation as proposed by SchINK and GuINASSo (1980) rather than by the magnitude of the organic decomposition reaction.

\section{Discussion}

In general the following biochemical processes are involved in marine nitrogen metabolism according to WADA and HATTORI (1971), Vaccaro (1965), Hooper (1978), Nicholas (1978) and KNOWLES (1978):

(3) Oxidative deamination

$$
\begin{aligned}
& \mathrm{R}_{2} \\
& \mathrm{R}_{1}-\mathrm{CH}\left(\mathrm{NH}_{2}\right)+\mathrm{H}_{2} \mathrm{O} \rightarrow \mathrm{R}_{1}-\mathrm{CO}+\mathrm{NH}_{3} \\
& +2 \mathrm{H}^{+}
\end{aligned}
$$

(4) Oxidation of ammonia

$$
\begin{array}{ll}
\mathrm{NH}_{4}^{+}+0.50_{2} & \stackrel{2 \mathrm{e}}{\rightarrow} \mathrm{NH}_{2} \mathrm{OH}+\mathrm{H}^{+} \\
\mathrm{NH}_{2} \mathrm{OH}+\mathrm{O}_{2} \stackrel{4 \mathrm{e}}{\rightarrow} \mathrm{NO}_{2}^{-}+\mathrm{H}_{2} \mathrm{O}+\mathrm{H}^{+}
\end{array}
$$

(5) Oxidation of nitrite

$$
\mathrm{NO}_{2}^{-}+0.5 \mathrm{O}_{2} \stackrel{2 \mathrm{e}}{\rightarrow} \mathrm{NO}_{3}^{-}
$$

Whereby deamination is not accompanied by any significant energy yield; however, the free energy changes from oxidation of ammonia and nitrite are $-59.4 \mathrm{kcal}$ and $-16.9 \mathrm{kcal}$, respectively.

In several experimental studies on decomposition of phytoplankton in seawtaer, voN BRAND and RAKESTRAw (1941) have shown that under controlled conditions of oxygen supply and in the absence of simultaneous phytoplankton growth bacterial nitrogen metabolism proceeds in sequential steps of deamination, fol- lowed by ammonium oxidation and finally by nitrite oxidation (Fig. 3). The sequence is suppressed when decomposable plankton matter was continuously supplied or had a "history" of earlier decomposition reactions. Hereby nitrate tended to dominate the metabolite concentrations suggesting concurrent reactions with nitrate formation being the fastest one.

In addition, similar experiments by VACCARO (1965) with monitoring of $\mathrm{PO}_{4}$ release, suggests that low $\mathrm{PO}_{4}$ yields, i.e. $\mathrm{NO}_{3}: \mathrm{PO}_{4}=16:<<1$, is typical for decomposing phytoplankton and higher $\mathrm{PO}_{4}$ yields for zooplankton. In summary then deamination accompanied by ammonium oxidation appears to be the first energy yielding reaction in microbial phytoplankton decomposition followed by nitrite oxidation; and these reactions are accompanied by low and nonstoichiometric $\mathrm{PO}_{4}$ yields.

In water column nutrient distributions the assimilatory processes in phytoplankton growth within the euphotic zone dominate nitrogen

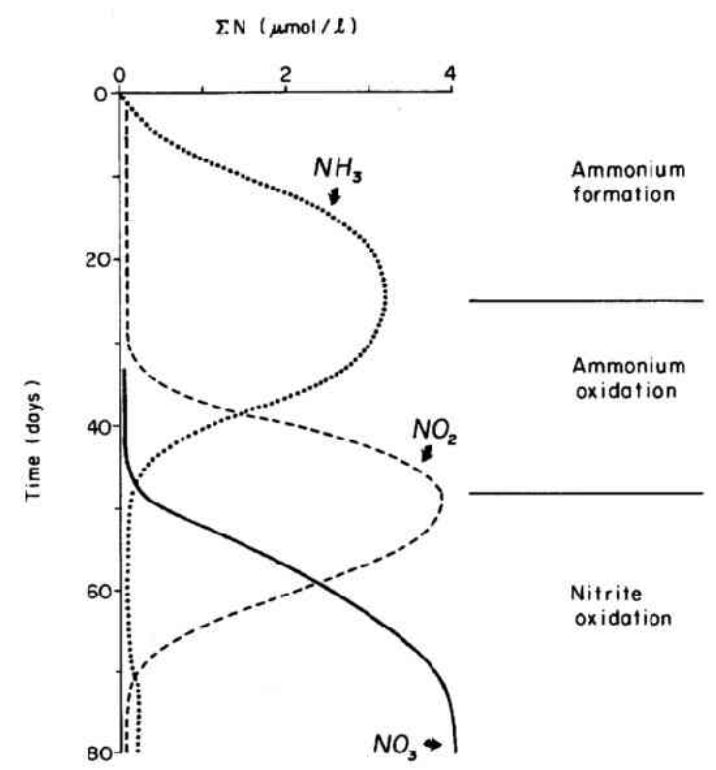

Fig. 3. Nitrogenous nutrient regeneration from phytoplankton in an experimental seawater system (after voN BRAND and RAKESTRAW et al., 1941; VON BRAND et al., 1942). Initially $\mathrm{NH}_{3}$ is formed by deamination then it is oxidized to $\mathrm{NO}_{2}$ and finally $\mathrm{NO}_{3}$ is formed from the oxidation of $\mathrm{NO}_{2}$. 
metabolism. But similarities to pore water nutrient distribution patterns can be expected below the euphotic zone where only bacterial metabolism is active. Accordingly we propose that oxidation of ammonia and oxidation of nitrite are two reactions in phytoplankton decomposition that may be encountered and compared in water column profiles below the euphotic zone and pore water profiles above the zone of denitrification.

As a comparison then a depth-concentration profile for dissolved $\mathrm{NO}_{3}, \mathrm{NO}_{2}, \mathrm{NH}_{3}, \mathrm{O}_{2}, \mathrm{PO}_{4}$ and $\mathrm{H}_{2} \mathrm{~S}$ from the Saanich Inlet water column is shown in Fig. 4. The data are from COHEN (1978), and are in general agreement with earlier work from the same area primarily by RICHARDS (1975) who pioneered stoichiometric modelling. Similar nutrient distribution patterns have been described from the N. Pacific and E. Atlantic (BRANDHORST, 1959; WADA and HATTORI, 1971; KIEFER et al., 1976; HERBLAND and VorTURIEZ, 1979).

Our discussion of the Saanich Inlet data is restricted to distribution patterns below $\sim 20 \mathrm{~m}$ of water depth where regeneration of nutrients exceeds consumption. Here nitrification is ac-

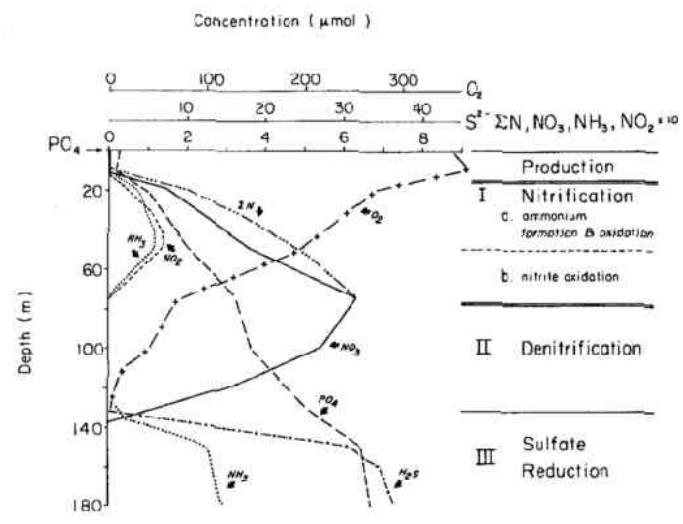

Fig. 4. Nutrient distribution in Saanich Inlet waters from COHEN (1978). Step (a) ammonia oxidation is characterized by $\mathrm{NH}_{3}$ and $\mathrm{NO}_{2}$ maxima; step (b) nitrite oxidation to $\mathrm{NO}_{3}$ is characterized by the disappearance of $\mathrm{NO}_{2}$ and $\mathrm{NH}_{3}$. companied by production of nitrogenous intermediaries (ammonia and nitrite) in a first step (between 20 and $50 \mathrm{~m}$ ), whereas they are fully oxidized to $\mathrm{NO}_{3}$ along with continued nitrification in a second step (between 50 and $75 \mathrm{~m}$ ). This zone is followed by denitrification between $75-120 \mathrm{~m}$ and eventually by sulfate reduction $>130 \mathrm{~m}$ of water depth. The nutrient distribution patterns there are not pertinent to this discussion. We suggest that the two-step nitrification process is a general recognizable phenomenon. Nitrification as it proceeds in the water column of Saanich Inlet waters below the zone of production is then analogous to nitrification in the near-surface sediment layer of oxic, pelagic sediments from the SW Pacific or as experimentally induced in decomposing phytoplankton matter. Although vastly different in magnitude and nature of assimilatory and respiratory processes, the three environments are dominated by microbiological activity and we suppose that organic matter respiration may in all cases be reflected first by maxima of partially oxidized nitrogenous intermediaries (ammonium and nitrite) followed by complete oxidation to nitrate (nitrification sensu strictu).

Nutrient distributions in the waters from Saanich Inlet and oxygen consumption permit stoichiometric modelling by calculating regenerative ratios for the three decomposition reactions (Table 2).

For regenerative ratios various normalizing parameters were chosen. For the initial step the change in $16 \mu \mathrm{M}$ of all nitrogenous species with depth was used; for the subsequent step ratios were calculated with respect to oxidation equivalents of $138 \mu \mathrm{M} \mathrm{O}_{2}$ and for denitrification with respect to $138\left(\mu \mathrm{M} \mathrm{O}_{2}+3 / 2 \mathrm{NO}_{3}\right)$. This scaling is based on the commonly accepted model reactions and allows direct comparison among the different reaction mechanisms. The results clearly indicate that within the initial step less $\mathrm{O}_{2}$ is consumed and less nitrate produced than expected from total nitrogenand $\mathrm{PO}_{4}$-regeneration assuming conventional Redfield ratios. This, however, is not unreasonable since the nitrogenous intermediate 
Table 2. Stoichiometry of nutrient regeneration in Saanich Inlet waters; data from COHEN (1978)

\begin{tabular}{cccccccccc}
\hline $\begin{array}{c}\text { Depth } \\
(\mathrm{m})\end{array}$ & $\frac{\Delta \mathrm{O}_{2}{ }^{1)}}{\Delta \mathrm{x}}$ & $\frac{\Delta \mathrm{NO}_{3}}{\Delta \mathrm{x}}$ & $\frac{\Delta \Sigma \mathrm{N}}{\Delta \mathrm{x}}$ & $\frac{\Delta \mathrm{PO}_{4}}{\Delta \mathrm{x}}$ & $\Delta \mathrm{O}_{2}:$ & $\Delta \mathrm{NO}_{3}: \Delta \Sigma \mathrm{N}:$ & $\Delta \mathrm{PO}_{4}$ & Reaction ${ }^{2)}$ \\
\hline $20-50$ & -2.57 & 0.356 & 0.476 & 0.0343 & -86 & 12 & $\underline{16}$ & 1.15 & Ia \\
$50-75$ & -5.00 & 0.545 & - & 0.0488 & $-138^{3)}$ & 15 & - & 1.35 & Ib \\
$75-120$ & -1.38 & -0.353 & - & 0.0300 & $\underline{-138^{4)}}$ & - & - & 2.10 & II \\
\hline
\end{tabular}

1) Change in concentration with depth in $\mu$ Moles $/ \ell / m$.

2) Ia $=$ Nitrification with intermediaries; $\mathrm{NH}_{3}$ and $\mathrm{NO}_{2}$.

$\mathrm{Ib}=$ Nitrification sensu strictu; $\mathrm{NO}_{2}$ oxidation.

II = Denitrification; not observed in SW Pacific pore water profiles.

3) Oxidation and nutrient equivalents normalized to species underlined.

4) Combined oxidation equivalents: $\Delta \mathrm{O}_{2}+3 / 2 \Delta \mathrm{NO}_{3}$.

compounds are only partially oxidized.

On the other hand in the subsequent step where nitrification proceeds from oxidation of $\mathrm{NO}_{2}$ without formation of intermediaries, the regeneration ratios are $15 \pm 0.5 \mu \mathrm{M}$ of $\mathrm{NO}_{3}$ and $1.35 \mu \mathrm{M}$ of $\mathrm{PO}_{4}$ for each $138 \mu \mathrm{M}$ of oxidation equivalents. These relationships are very close to the ideal ratios and persist also through denitrification except for an increase in $\mathrm{PO}_{4}$ regeneration with depth. Here $2.16 \mu \mathrm{M}$ of $\mathrm{PO}_{4}$ are regenerated from consumption of the combined oxidation equivalents of free oxygen and nitrate. Other nitrogenous end products of this reaction are presumably $\mathrm{N}_{2} \mathrm{O}$ and $\mathrm{N}_{2}$, whose combined total should be $\sim 16 \mu \mathrm{M}$, but which are generally not determined. Not available from these hydrographic data are measurements of changes in $\mathrm{CO}_{2}$-contents which should provide further support for our interpretations.

This interpretation then yields a consistent picture of organic matter decomposition in the upper water column and in the upper sediment column. We see its consistency in the predictable nitrogenous nutrient generation involving three different reaction mechanisms, i.e. deamination, ammonium oxidation and nitrite oxidation. The formation and persistence of nitrogenous intermediaries appear to be characteristic and measurable features of initial nitrification in this steady state process.

In attempting to apply the above model to the pore water data of the SW Pacific sediments, a convenient normalizing paramerer - such as $\mathrm{PO}_{4}, \mathrm{O}_{2}$ or $\mathrm{CO}_{2}-$ is not readily available. Changes in dissolved phosphate to be used here require a high analytical precision since the total magnitude of nutrient changes is rather small. Also $\mathrm{PO}_{4}$ is known to readily undergo secondary reactions by sorption (BERNER, 1976) and furthermore the depletion in P-org of the decomposing phytoplankton matter makes use of the Redfield ratios as such a parameter slightly uncertain. On the other hand the largest changes in metabolic quantities affect the $\Sigma \mathrm{CO}_{2}$. Here our data - although not very accurate - would allow sufficiently precise changes in $\Sigma \mathrm{CO}_{2}$ to be used if it were not for the possibility of substantial losses in alkalinity due to effects of pressure release. MURRAY et al. (1980) have recently documented that alkalinity and $\mathrm{pH}$ measured in situ are systematically higher than values from deep sea samples obtained by box coring. They suggest that this is due to instantaneous precipitation of $\mathrm{CaCO}_{3}$ induced by pressure release.

Nevertheless we have modelled the interstitial nutrient data of Core 7812-14 from the siliceous clay facies (Table 3) analogous to the distribution pattern of Saanich Inlet waters (Table 2). The changes in concentration with depth of nitrogenous species $\mathrm{NO}_{3}$ and $\Sigma \mathrm{N}$ are normalized to those of $\mathrm{PO}_{4}$. Again for the initial step - between $0-8 \mathrm{~cm}$ of depth - the observed change in $\mathrm{NO}_{3}$ is smaller than predicted from the Redfield ratios i.e. $<16$, whereas total nitrogen generation approaches the value of 16 , 
Table 3. Stoichiometry of nutrient regeneration in pore waters from the siliceous clay facies (Core 7812-14) of the SW Pacific Basin

\begin{tabular}{|c|c|c|c|c|c|c|c|}
\hline $\begin{array}{l}\text { Depth } \\
\text { (cm) }\end{array}$ & $\frac{\Delta \mathrm{NO}_{3}{ }^{1}{ }^{1}}{\Delta \mathrm{x}}$ & $\frac{\Delta \Sigma \mathrm{N}}{\Delta \mathrm{x}}$ & $\frac{\Delta \mathrm{PO}_{4}}{\Delta \mathrm{x}}$ & $\Delta \mathrm{NO}_{3}$ & $\Delta \Sigma \mathrm{N}$ & $: \quad \Delta \mathrm{PO}_{4}$ & Reaction $^{2)}$ \\
\hline $0-2$ & 1.80 & 3.47 & 0.20 & 9 & 17 & $1^{3)}$ & \multirow{4}{*}{ Ia } \\
\hline 2- 4 & 1.11 & 1.77 & 0.10 & 11 & 17 & 1 & \\
\hline 4- 6 & 1.06 & 1.21 & 0.08 & 12 & 16 & 1 & \\
\hline 6- 8 & 0.93 & 1.01 & 0.06 & 13 & 15 & 1 & \\
\hline $8-10$ & 0.78 & 0.85 & 0.06 & 14 & 15 & 1 & \multirow{6}{*}{$\mathrm{Ib}$} \\
\hline $10-13$ & 0.62 & 0.65 & $0.01(?)$ & & & & \\
\hline $16-19$ & 0.40 & 0.45 & 0.03 & 14 & 16 & 1 & \\
\hline $22-25$ & 0.29 & 0.35 & 0.02 & 14 & 16 & 1 & \\
\hline $31-34$ & 0.26 & 0.29 & 0.02 & 14 & 16 & 1 & \\
\hline $34-37$ & 0.23 & 0.25 & 0.02 & 14 & 15 & 1 & \\
\hline
\end{tabular}

1) Change in concentration with depth in $\mu$ Moles $/ \mathrm{l} / \mathrm{cm}$.

2) Step (a) ammonium and nitrite formation.

Step (b) nitrite oxidation to $\mathrm{NO}_{3}$.

3) Nutrient equivalents normalized to $\mathrm{PO}_{4}=1$.

thus emphasizing $\mathrm{NH}_{3}$ and $\mathrm{NO}_{2}$ formation. In the subsequent reaction step - between $8-37 \mathrm{~cm}$ of depth $-\mathrm{NO}_{2}$ is largely oxidized to $\mathrm{NO}_{3}$ at the expected proportions relative to $\mathrm{PO}_{4}$.

In summary then we propose hypothetical depth-concentration profiles of the chemical species involved in the two-step overall nitrification process (Fig. 5). The zone of nitrification is subdivided into an upper layer which is characterized by ammonia and nitrite formation and a lower layer characterized by nitrite oxidation to $\mathrm{NO}_{3}$. These layers are also reflected in different oxygen distributions. The deepest layer is devoid of oxygen; it is characterized by denitrification. All nutrient concentration changes are normalized to a constant dissolved $\mathrm{PO}_{4}$ increase downcore.

It is of great importance that in future pore water studies dissolved oxygen measurements be included, and provisions be made to obtain highly accurate $\Sigma \mathrm{CO}_{2}$ and $\mathrm{PO}_{4}$ profiles within the first $30 \mathrm{~cm}$ of the sediment water interface. Because, if once it is shown that nitrification proceeds in two steps as we suggest, then the distribution of the nitrogenous species alone can be used to precisely delineate zones of oxic diagenesis. Of these nitrogenous indicator species $\mathrm{NO}_{3}, \mathrm{NO}_{2}, \mathrm{NH}_{3}$ and total DON are important and $\mathrm{NH}_{2} \mathrm{OH}$ should be included as well. The zones of oxic diagenesis are thin, being in the range of centimeters only, but surely exert a strong influence on the inorganic and organic chemical composition of the pelagic sediment record, and nutrient regeneration from the sediment-water interface.

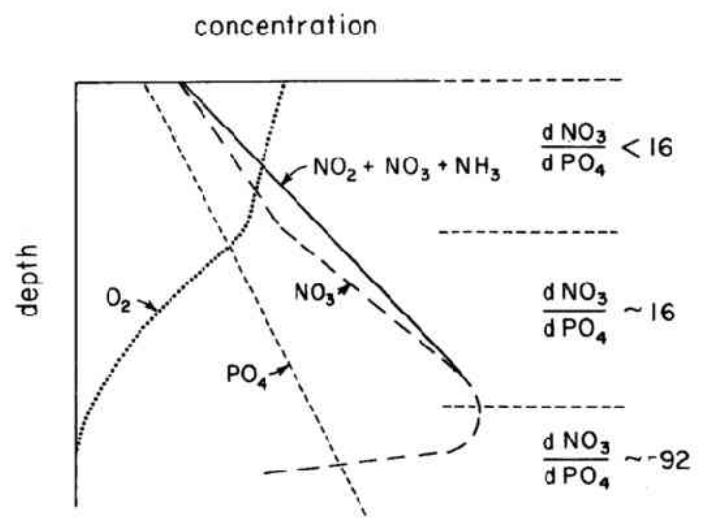

Fig. 5. Hypothetical nutrient distribution profile in oxic pelagic sediments. The zone of nitrification is subdivided into an upper layer which is characterized by formation of nitrite and ammonia and a lower layer characterized by nitrate formation. These layers are also reflected by particular oxygen distributions. Below these is a layer devoid of oxygen in which denitrification takes place. All nutrient concentration changes are normalized to a constant dissolved $\mathrm{PO}_{4}$ increase downcore. 
Acknowledgements-This research was supported by the National Science Foundation to study the Fractionation of Bio-conveyed Elements at the Sea Floor, Grant OCE-7720376 to Oregon State University. We owe thanks to RV KNORR's crew and captain for able support at sea, to J. BAROSS for fruitful discussions and to G. DAVIS and P. KALK for valuable assistance.

\section{REFERENCES}

ALLER, R. C. (1977) The influence of macrobenthos on chemical diagenesis in marine sediments. Unpublished Ph.D. dissertation, Yale University, New Haven, Conn., 600 p.

BALZER, W. (1978) Untersuchungen über Abbau organischer Materie und Nährstoff-Freisetzung am Boden der Kieler Bucht beim Übergang vom oxischen zum annoxischen Milieu. Ph.D. dissertation, Kiel University, $230 \mathrm{p}$.

Bender, M. L., Fanning, K. A., Froelich, P. N., HEATH, G. R. and MAYNARD, V. (1977) Interstitial nitrate profiles and oxidation of sedimentary organic matter in the eastern Equatorial Atlantic. Science 198: 605-608.

BERNER, R. A. (1972) Sulfate reduction, pyrite formation, and the oceanic sulfur budget. In: D. DYRSSEN and D. JAGNER (Editors), The Changing Chemistry of the Oceans, Nobel Symposium 20, Almquist and Wiksell, Stockholm, pp. 347-361.

BERNER, R. A. (1976) Phosphate removal from seawater by adsorption on volcanogenic ferric oxides. Earth Planet. Sci. Lett. 29, 333-340.

BERNER, R. A. (1977) Stoichiometric models for nutrient regeneration in anoxic sediments. Limnol. Oceanogr. 22, 781-786.

Von BRAND, T. and RAKestraW, N. W. (1941) Decomposition and regeneration of nitrogenous organic matter in seawater. IV. Interrelationship of various stages; influence of concentration and nature of particulate matter. Biol. Bull. 81, 63-69.

VON BRAND, T., RAKESTRAW, N. W. and ZABOR, J.W. (1942) Decomposition and regeneration of nitrogenous organic matter in seawater. V. Factors influencing the length of the cycle; observations upon the gaseous and dissolved organic nitrogen. Biol. Bull. 83, 273-282.

BRANDHORST, W. (1959) Nitrification and denitrification in the eastern tropical North Pacific. J. Cons. Intl. Exlor. Mer. 25, 3-20.

COHEN, Y. (1978) Studies on the marine chemistry of nitrous oxide. Ph.D. dissertation, Oregon State University, Corvallis, Oregon, $112 \mathrm{p}$.

EMERSON, S. (1976) Early diagenesis in anaerobic lake sediments: chemical equilibria in interstitial waters. Goechim. Cosmochim. Acta 40, 925-934. Froelich, P. N., Klinkhammer, G. P., Bender, M. L., LuedtKe, N. A., Heath, G. R., Cullen, D., Dauphin, P., Hammond, D., HaRtman, B. and MAYNARD, V. (1979) Early oxidation of organic matter in pelagic sediments of the eastern Equatorial Atlantic: suboxic diagenesis. Geochim. Cosmochim. Acta 43, 1075-1090.

Gordon, L. I., BarSTOW, L., LILly, M., SEIFERT, E. H. and PARK, P. K. (1975) Method report for total organic carbon measurements. GEOSECS Ref. 75-12, School of Oceanography, Oregon State University, Carvallis, $46 \mathrm{p}$.

HaRTMANN, M., MÜller, P., SUess, E. and VAN DER WEIJDEN, C. H. (1976) Chemistry of Late Quaternary sediments and their interstitial waters from NW African continental margin. "Meteor" Forsch.Ergebn., C 23: 1-67.

HERBLAND, A. and VoITURIEZ (in press) The use of the vertical distribution of temperature, oxygen, and nutrients for estimating chlorophyll and primary production in the tropical Atlantic Ocean. Centre de Recherches Oceanographiques, $21 \mathrm{p}$.

HOOPER, A. B. (1978) Nitrogen oxidation and electron transport in ammonia-oxidizing bacteria. In: D. SCHLESSINGER (Editor), Microbiology - 1978, American Soc. for Microbiology, Washington, p. 299-304.

Kiefer, D. A., Olson, R. J. and Holm-Hansen, O. (1976) Another look at the nitrite and chlorophyll maxima in the central North Pacific. Deep-Sea Research 23, 1199-1208.

KNOWLES, R. (1978) Common intermediates of nitrification and denitrification and the metabolism of nitrous oxide. In: D. SCHLESSINGER (Editor), Microbiology - 1978, American Soc. for Microbiology, Washington, p. 367-371.

MARTENS, C. S., BERNER, R. A. and Rosenfeld, J. (1978) Interstitial water chemistry of Long Island Sound sediments: 2 . Nurtient regeneration and phosphate removal. Limnol. Oceanogr. 23, 605-617.

MIYAZAKI, T., WADA, E. and HATTORI, A. (1973) Capacities of shallow waters of Sagami Bay for oxidation and reduction of inorganic nitrogen. Deep-Sea Res. 20, 571-577.

MURRAY, J. and IRVINE, R. (1895) Chemical changes between seawater and oceanic deposits. Nature (London) 51, 304-306.

MURRAY, J. W., GRUNDMANIS, V. and SMETHIE, JR., W. M. (1978) Interstitial water chemistry in sediments of Sannich Inlet. Geochim. Cosmochim. Acta 42, 1011-1026.

MURRAY, J. W., EMERSON, S. and JAHNKE, R. (1980) Carbonate saturation and the effect of pressure on 
the alkalinity of interstitial waters from the Guatemala Basin. Geochim. Cosmochim. Acta 44, 963-972.

NiCHOLAS, D. J. D. (1978) Intermediary metabolism of nitrifying bacteria, with particular reference to nitrogen, carbon, and sulfur compounds. In: D. SCHLESSINGER (Editor). Microbiology - 1978, American Soc. for Microbiology, Washington, p. 367371.

PACKARd, T. T., Dugdale, R. C., Goering, J. J. and BARBER, R. T. (1978) Nitrate reductase activity in the subsurface waters of the Peru Current. J. Mar. Res. 36, 59-76.

RICHARDS, F. A. (1965) Anoxic basins and fjords. In: J. P. RILEY and G. SKIRROW (Editors), Chemical Oceanography, v. 1, Academic Press, p. 611-645.
SchINK, D. R. and Guinasso, JR., N. L. (in press) Processes affecting silica at the abyssal sediment-water interface. Colloq. Internat. du C.N.R.S., No 293 Biogeochimie de la Matière Organique a l'Interface Eau. Sédiment Marin. Paris/France.

SUESS, E. (1979) Mineral phases formed in anoxic sediments by microbial decomposition of organic matter. Geochim. Cosmochim. Acta, 43, 338-352.

VACCARO, R. F. (1965) Inorganic nitrogen in seawater. In: J. P. RILEY and G. SKIRROW (Editors), Chemical Oceanography, v. 1, Academic Press, pp. 365-408.

WADA, E. and HATTORI, A. (1971) Nitrite metabolism in the euphotic layer of the central North Pacific Ocean. Limnol. Oceanogr., 16, 766-772. 